\title{
E 103
}

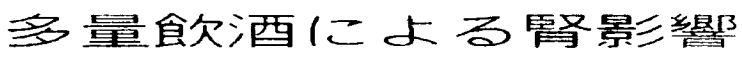

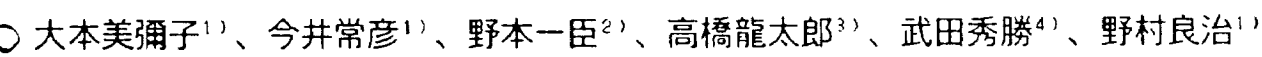

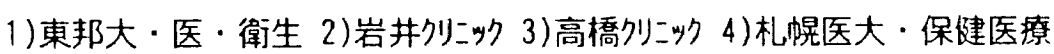

【はじめに】多量長期飲酒者における肝影響は周 知である。しかし腎影響の指摘は皆無に等しい。我 々は種々の投与開始時期・期間による系統的観察結 果により肝影響より早期に腎影響が観察されること を1982年に報告し、以来、腎機能生化学的指標に有 意の変動のあることも検証し1986年本学会において 特別報告した。その後の観察において17个月間飲酒う 叶の断酒48時間経過時の腎中遊離型I 投与群の2.3倍、結合型I夕)-ル(B-Et)は2.3倍で血中の

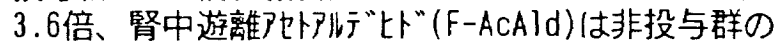

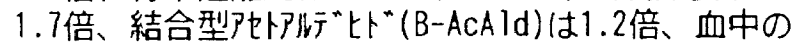
1.8倍が存在し、96時間後においてもB-Etは1.3倍、 B-AcAldは1.2倍が存在したこと、督組織学的所見に おいては傍系球体細胞の增殖、系球体内PAS陽性物質 の沈着、尿細管上皮細胞の委縮、塩基性尿細管、尿 円柱などの所見が観察されたが同一動物群の肝には 対照群に比較し殆ど影響が見られなかったことの結 果を得ている。そこで、これら動物による基整研究 成果を心まえ、多量長期飲酒者について観察したと ころ同様の結果が得られたのでここに紹介し健康教 育に資すべく報告する。

【観察方法】男子多量長期飲酒者 (年齢39-68才) 22名および対照群として男子少量飲酒及至中等量低 頻度飲酒者（年齢45-55才）10名について洗浄赤血球 中のF-ACAld、B-ACAld, renin活性、ACE活性、angi otensin 1、angiotensin $11,1 \alpha, 25(\mathrm{OH})_{2} \mathrm{D}_{3}, 24$, $25(O H)=D: 25(O H) D$ : erythropoietin,GOT、GPT、 $r$-GTP、LPO、等を測定した。

赤血球中遊離型・結合型ACAld量は、洗浄赤血球を 等量の蒸留水で溶血させPCA処 理し遊離型試料とし、同様に溶 血させ、10\% $\mathrm{H}_{2} \mathrm{SO}_{4}$ にて加水分解 後PCA処理し、結合型試料とし、 GC9000(PEG20M)により测定した。erythropoiet in $\mathrm{mU} / \mathrm{ml}$

Renin活性およびAngiotensin 1、II、ACE活性はRIA法により、 $1 \alpha, 25(\mathrm{OH})=20$ : はRRA法、25(OH) $D: 24,25(\mathrm{OH}): \mathrm{D}$ : はCPBA法、 erythropoietinはRIA法、その 他の項目については常法により 測定した。有意差検定はStudent angiotensin $1 \mathrm{pg} / \mathrm{ml}$ t-testによつた。

【結果】Tableに示すように 多量長期飲酒者群において赤血 球中ACAId量は遊離型、結合型 いずれも対照群の少量飲酒者群 に比較して高値を示し、Fーおよ びBーACAld量は有意であった( $\mathrm{p}$ $<0.01)$ 。renin, ACE活性、Angi otensin 1についてもも多量長 期飲酒者群において有意 $(\mathrm{p}<$ 0.01)に高值を示した。Angio tensin 11 , erythropoietin 、 $1 \alpha, 25(\mathrm{OH})_{2} \mathrm{D}_{3}$ に関 しては多量長期飲酒者群において極めて高値の例が 観察され、対照群のM士2SD を超える估を示す多量長 期飲酒者は全例の30〜 50\%に観察された。

【考察】これまでの一連の研究経過の中で、ラ师に I夕ノ-11回投与で遊離型、結合型ACAIdが約8時間後に 尿中濃度が最高値になること、1ケ月間投与でACE、1 $\alpha, 25(\mathrm{OH})_{2} \mathrm{D}_{3} 、 24,25(\mathrm{OH})_{2} \mathrm{D}_{3}$ に有意の変動の起るこ と、この時点で既に腎組織所見として糸球体腫脹、 基底膜肥厚、PAS陽性物質沈着、メ将ギウム細胞增殖、 傍系球体細胞增殖、尿細管管腔拡張、上皮細胞腫脹、 脱落、硝子様滴、間質への細胞浸潤、塩基性尿細管 が観察され、さらに17个月間投与実験で冒頭に記した 如く17个月投与実験で4日間I夕/-1摂取の無い条件下に おいても腎中に結合型Et、ACAldの存在が明らかとな り組織所見も一層明確となりACAId結合体の抗原性に より産生された抗体が系球体内PAS陽性物質として沈 着し膜性腎炎様変化として観察されると考えられた。 此度の多量長期飲酒者の場合も3力月〜2力年間の断酒 が継続された被験者であることをふまえ、肝機能指 標に異常高值が示されないにも拘らずrenin活性、A CE活性、Angiotensin I、11の高値、erythropoiet in 、 $1 \alpha, 25(\mathrm{OH})_{2} \mathrm{D}_{3}$ 等の高值者の存在は、飲酒の腎 影響を指摘するものであり飲酒に関する健康教育の 上に活かされるべきことの必要性が示唆されたもの である。

本研究は日本大学医学部法医学教室塚本昭次郎助 教授との共同研究である。

本研究の一部は文部省科研費の助成による。

\begin{tabular}{|c|c|c|c|c|c|c|c|}
\hline \multirow[b]{2}{*}{ ACE } & \multirow[b]{2}{*}{ IU/I } & \multicolumn{2}{|r|}{ 少墨飲酒群 } & \multirow[b]{2}{*}{ (22) } & \multicolumn{2}{|l|}{ 多毁長期飲酒群 } & \\
\hline & & (7) & $14.50 \pm 3.94$ & & $23.59 \pm 9.33$ & ** & \\
\hline erythropoietin & $\mathrm{mU} / \mathrm{ml}$ & (7) & $16.59 \pm 5.14$ & (2) & $\begin{array}{c}>40 \\
49.30 \pm 12.16\end{array}$ & (14) & $\begin{array}{c}<40 \\
19.85 \pm 5.79\end{array}$ \\
\hline renin & $\mathrm{mg} / \mathrm{ml} / \mathrm{hr}$ & (7) & $1.49 \pm 1.13$ & $(8)$ & $\begin{array}{l}>2.0 \\
4.51 \pm 3.09\end{array}$ & * (14) & $\begin{array}{c}<2.0 \\
1.03 \pm 0.56\end{array}$ \\
\hline $1 \alpha, 25(0 \mathrm{H})_{2} D_{3}$ & $\mathrm{ng} / \mathrm{ml}$ & (7) & $27.09 \pm 6.92$ & (6) & $\begin{array}{c}>40 \\
49.98 \pm 3.77\end{array}$ & $\$ *(15)$ & $\begin{array}{c}<40 \\
25.27 \pm 5.80\end{array}$ \\
\hline angiotensin 1 & $\mathrm{pg} / \mathrm{ml}$ & (7) & $451.43 \pm 68.42$ & $\begin{array}{l}(22) \\
(16)\end{array}$ & $\begin{array}{c}1044.09 \pm 546.65 \\
>600 \\
1254.37 \pm 495.16\end{array}$ & $\neq *$ & $\begin{array}{c}<600 \\
483.33 \pm 25.82\end{array}$ \\
\hline angiotensin 11 & $p g / m l$ & (7) & $32.71 \pm 10.29$ & (11) & $\begin{array}{c}>50 \\
108.18 \pm 110.13\end{array}$ & * (11) & $\begin{array}{l}<50 \\
26.09 \pm 11.30\end{array}$ \\
\hline $\begin{array}{l}\text { GOT } \\
\text { GPT } \\
\gamma-G T P \\
\text { LPO }\end{array}$ & $\begin{array}{l}\mathrm{IU} / 1 \\
\mathrm{IU} / \mathrm{I} \\
\mathrm{IU} / \mathrm{l} \\
\mathrm{nmol} / \mathrm{ml}\end{array}$ & $\begin{array}{l}(7) \\
(7) \\
(7) \\
(7)\end{array}$ & $\begin{array}{c}31.57 \pm 11.01 \\
20.14 \pm 10.22 \\
23.57 \pm 9.13 \\
1.97 \pm 0.63\end{array}$ & $\begin{array}{l}(22) \\
(22) \\
(22) \\
(22)\end{array}$ & $\begin{array}{c}34.56 \pm 26.63 \\
19.75 \pm 11.52 \\
44.06 \pm 26.49 \\
2.89 \pm 2.48\end{array}$ & * & \\
\hline $\begin{array}{l}\text { F-AcAld } \\
B-A C A l d\end{array}$ & $\begin{array}{l}n \mathrm{~mol} / \mathrm{g} \mathrm{H} \\
\mathrm{nmol} / \mathrm{g} \mathrm{H}\end{array}$ & $\begin{array}{l}b(7) \\
b(7)\end{array}$ & $\begin{array}{r}7.43 \pm 1.51 \\
48.64 \pm 7.66\end{array}$ & $\begin{array}{l}(22) \\
(22)\end{array}$ & $\begin{array}{c}28.01 \pm 8.23 \\
120.06 \pm 52.92\end{array}$ & $\begin{array}{l}* * \\
* *\end{array}$ & \\
\hline
\end{tabular}

